\title{
Glucose regulates both glucose transport and the glucose transporter gene expression in a hamster-derived pancreatic Beta-cell line (HIT)
}

\author{
F. Purrello, M. Buscema, M. Vetri, C. Vinci, C. Gatta, F. Forte, A.M. Rabuazzo and R. Vigneri \\ Cattedra di Endocrinologia, University of Catania Medical School, Catania, Italy
}

\begin{abstract}
Summary. We studied the effect of chronic exposure to high glucose on the glucose transport regulation in hamster pancreatic Beta cells in permanent culture (HIT). Cells were exposed to either $5.5 \mathrm{mmol} / \mathrm{l}$ or $16.7 \mathrm{mmol} / \mathrm{l}$ glucose for $48 \mathrm{~h}$ and then glucose transport was studied by measuring the $\left({ }^{3} \mathrm{H}\right)$-2-deoxyglucose uptake for 5 and $10 \mathrm{~min}$ at $37^{\circ} \mathrm{C}$. The 2deoxyglucose uptake was lower in cells pre-exposed to glucose $16.7 \mathrm{mmol} / \mathrm{l}$ for $48 \mathrm{~h}$ compared to cells pre-exposed to glucose $5.5(12.0 \pm 1.6 \mathrm{vs} 19.1 \pm 1.2 \mathrm{nmol} / 0.1 \mathrm{mg}$ after $5 \mathrm{~min}$, and $22.2 \pm 2.6$ vs $39.0 \pm 2.9$ after 10 min respectively, mean \pm SEM, $n=5, p<0.01)$. In order to investigate the mechanism(s) for glucose impairment of glucose transport, we studied the glucose carrier gene expression in the same cells by Northern and slot-blot analysis. When total RNA was extracted from HIT cells cultured at either 5.5 or $16.7 \mathrm{mmol} / 1$ glucose and then hybridized to ${ }^{32} \mathrm{P}$-labelled cDNA probes for the glucose transporter 1 , the glucose transporter 2 and $\beta$ actin, a significant reduction of both glucose transporter 1
\end{abstract}

$(-63.9 \pm 4.1 \%$, mean \pm SEM, $n=3)$ and glucose transporter $2(-48.9 \pm 3.2 \%)$ mRNA was observed in HIT cells cultured with high glucose. In the same experiments no change of $\beta$-actin mRNA was observed, suggesting that the effect of high glucose was specific on the glucose-transporter mRNAs. In HIT cells cultured at glucose $16.7 \mathrm{mmol} / 1$ the glucose-induced insulin release was also reduced compared to cells cultured at glucose $5.5\left(715 \pm 19 \mu \mathrm{U} \cdot \mathbf{h}^{-1} \cdot \mathrm{mg}^{-1}\right.$ vs $1301 \pm 28 \mu \mathrm{U} \cdot \mathrm{h}^{-1} \cdot \mathrm{mg}^{-1}$, respectively, mean $\pm \mathrm{SEM}, n=3$, $p<0.05)$. In conclusion, in hamster pancreatic Beta-cells, chronic exposure to high glucose concentrations impairs glucose transporter mRNA levels, glucose transport, and glucose-induced insulin secretion in a co-ordinate manner.

Key words: Glucose transport, glucose transporters, insulin secretion, pancreatic Beta cells, chronic high glucose.
Glucose represents the major source of energy for mammalian cells and, in addition, also plays a primary role as a regulator of insulin secretion. Changes in plasma glucose are immediately reflected in the insulin-producing Beta cell since glucose is transported into the cell via a carriermediated system of facilitated transport. A family of structurally related glucose carrier proteins which accelerate glucose transport down its concentration gradient by facilitative diffusion [1] has been recently described. These glucose transporters are expresse in a tissue-specific manner, have different biochemical properties, and are regulated by various nutrients and hormones under varying physiological states (i.e. fasting and feeding). The major protein responsible for glucose transport in pancreatic Beta cells has been reported to be a 55 kilodalton protein with an identical primary sequence to the glucose transporter isoform isolated in the liver (Glut-2, or Liver type) [2], being expressed also in kidney and intestinal cells and having the highest $\mathrm{K}_{\mathrm{m}}$ for glucose in the glucose transporter family.
The mechanism(s) of the Beta-cell glucose transporter regulation are still unknown. Chronic hyperglycaemia has been reported to contribute to peripheral insulin resistance through a down-regulation of the glucose transport system in peripheral tissues. Ambient glucose concentration regulates glucose transport in a variety of cell types, and in this way low glucose enhances, or high glucose decreases glucose transporter activity in adipocytes [3] and miocytes [4].

In the present study we have investigated as to whether glucose can regulate glucose transport and if alterations in glucose transport may, in turn, affect insulin secretion in Beta cells.

We exposed a line of hamster pancreatic cells in permanent culture (HIT cells), commonly used for studying Beta-cell function and metabolism, to different glucose concentrations. In these cells we studied glucose transport, the glucose transporter gene expression and glucoseinduced insulin secretion. 


\section{Materials and methods}

\section{Reagents}

Culture medium RPMI-1640, heat-inactivated fetal calf serum (FCS), glutamine and antibiotics were purchased from Gibco (Glasgow, UK). Bovine serum albumin (BSA) and 2-deoxy-D-glucose (2DG) were obtained from Sigma (London, UK). 2-deoxy-D$\left[1-{ }^{3} \mathrm{H}\right]$ glucose $\left[\left({ }^{3} \mathrm{H}\right)-2 \mathrm{DG}\right]$, specific activity $17 \mathrm{Ci} / \mathrm{mmol}$, was from Amersham, (Amersham, UK). The cDNA probe for the glucose transporter 1 (Glut-1) was kindly provided by Dr. M. Mueckler (St.Louis, Mo., USA) and the cDNA for glucose transporter 2 (Glut-2) was kindly provided by Dr. H. Lodish and B.Thorens (Cambridge, Mass., USA).

\section{Cells}

HIT pancreatic cells in permanent cultures were kindly provided by Dr. R.P. Robertson (Minneapolis, Minn., USA) and were grown in $5 \% \mathrm{CO}_{2} / 95 \%$ air in RPMI-1640 medium containing $10 \%$ FCS and $11.1 \mathrm{mmol} / \mathrm{l}$ glucose. All the experiments were performed with culture passages 7480 .

For the studies of insulin secretion and the $\left({ }^{3} \mathrm{H}\right)$-2DG uptake experiments HIT cells were plated at a concentration of $\sim 3 \times 10^{5}$ cells/well in 12 -well tissue culture plates (Corning, NY, USA). For the preparation of total cellular RNA, HIT were plated at a concentration of $\sim 3 \times 10^{6}$ cells $/ 100 \mathrm{~mm}$ in plastic tissue culture dishes. In both cases cells were first cultured for $72 \mathrm{~h}$ in RPMI-1640 medium supplemented with $10 \% \mathrm{FCS}$ and $2 \mathrm{mmol} / 1$ glutamine. The medium was then changed to a fresh medium containing glucose at either 5.5 or $16.7 \mathrm{mmol} / \mathrm{l}$ and cultured for an additional $48 \mathrm{~h}$. At the end of this culture period the following studies were performed:

$\left({ }^{3} H\right)$ 2-deoxy-D-glucose uptake. The culture medium was removed, the cells washed twice and incubated for $30 \mathrm{~min}$ at $37^{\circ} \mathrm{C}$ with KrebsRinger-Phosphate (KRP) buffer $(140 \mathrm{mmol} / 1 \mathrm{NaCl}, 1.7 \mathrm{mmol} / 1 \mathrm{KCl}$, $0.9 \mathrm{mmol} / \mathrm{l} \mathrm{CaCl}, 1.47 \mathrm{mmol} / 1 \mathrm{~K}_{2} \mathrm{HPO}_{4}, 0.8 \mathrm{mmol} / 1 \mathrm{MgSO}_{4}$, and $0.5 \%$ BSA, pH 7.4). The buffer was then replaced with $1 \mathrm{ml}$ of fresh $\mathrm{KRP}$ containing $\left({ }^{3} \mathrm{H}\right)-2 \mathrm{DG}(0.4 \mu \mathrm{Ci} / \mathrm{ml}, 1.0 \mathrm{mmol} / \mathrm{l}$ final concentration). After 5 and $10 \mathrm{~min}$ at $37^{\circ} \mathrm{C}$ the uptake was stopped by washing the cells three times with ice-cold KRP containing $0.5 \%$ BSA and $100 \mathrm{mmol} / \mathrm{l} \mathrm{D}$-glucose $\mathrm{pH}$ 7.4. Cells were then solubilized with $1 \mathrm{ml}$ $0.1 \%$ sodium dodecyl sulfate (SDS), and the cell-incorporated radioactivity was counted in a $\beta$-counter. Counts were normalized to the protein content in each well.

Northern and slot-blots. Total cellular RNA was extracted in accordance with the guanidinium-isothiocyanate method from $2-4 \times 10^{7} \mathrm{HIT}$ cells and denaturated in formaldehyde. For Northern transfers, $20 \mu \mathrm{g}$ of RNA were subjected to electrophoresis in $1 \%$ agarose, and transferred to nitrocellulose paper. For slot blots, $5 \mu \mathrm{g}$ of RNA were immobilized to nitrocellulose using a Slot Blot Minifold apparatus (Schleicher \& Schuell, Keene, NH, USA). Glut-1, Glut-2 and $\beta$-actin cDNA were labelled with ${ }^{32} \mathrm{P}$-dCTP by nick translation (Amersham). The nitroceliulose filters were prehybridized, then hybridized with the denaturated nick translated cDNA probes, and washed at high stringency conditions in order to prevent crosshybridization. Hybridization was visualized by autoradiography using Amersham hyperfilm and intensifying screens at $-80^{\circ} \mathrm{C}$. The relative abundance of the RNA message was quantified by densitometry (LKB, Bromma, Sweden).

Insulin secretion. HIT cells cultured for $48 \mathrm{~h}$ in the presence of either 5.5 or $16.7 \mathrm{mmol} / \mathrm{l}$ glucose were washed twice and incubated for $30 \mathrm{~min}$ at $37^{\circ} \mathrm{C}$ in Krebs-Ringer buffer (KRB) containing $119 \mathrm{mmol} / 1 \mathrm{NaCl}, 4.74 \mathrm{mmol} / 1 \mathrm{KCl}, 2.54 \mathrm{mmol} / 1 \mathrm{CaCl}_{2}, 1.19 \mathrm{mmol} / \mathrm{l}$ $\mathrm{MgSO}_{4}, 1.19 \mathrm{mmol} / \mathrm{K} \mathrm{KH}_{2} \mathrm{PO}_{4}, 25 \mathrm{mmol} / \mathrm{l} \mathrm{NaHCO}$, and $10 \mathrm{mmol} / \mathrm{l}$ Hepes at $\mathrm{pH} 7.4$ and $0.1 \%$ BSA. Static incubations were then performed for $1 \mathrm{~h} \mathrm{in} \mathrm{KRB} \mathrm{containing} \mathrm{glucose} \mathrm{at} \mathrm{either} 0.8 \mathrm{mmol} / \mathrm{l}$ (to study basal insulin secretion) or $16.7 \mathrm{mmol} / \mathrm{l}$ (to study glucose-in-

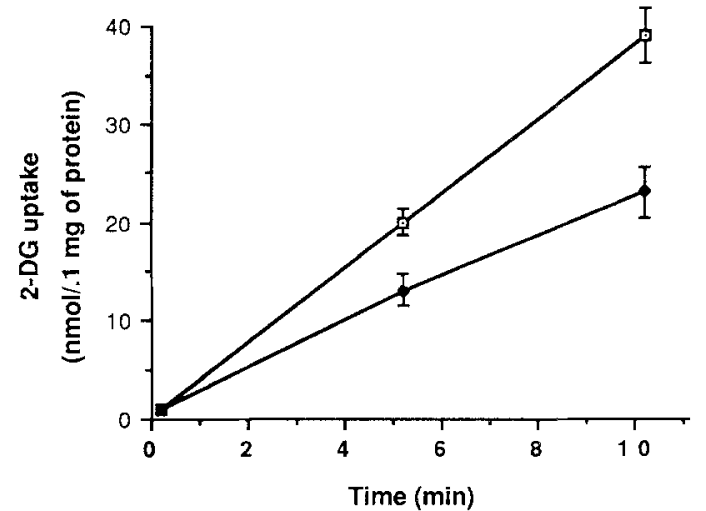

Fig. 1. 2-Deoxyglucose (2-DG) uptake in pancreatic HIT cells exposed to either 5.5 or $16.7 \mathrm{mmol} / \mathrm{l}$ glucose. HIT cells were cultured in RPMI-1640 medium supplemented with $10 \%$ fetal calf serum and containing glucose at either $5.5 \square$ or $16.7-\mathrm{mmol} / \mathrm{l}$. At the end of this period, the culture medium was removed, and the cells washed twice and incubated for $30 \mathrm{~min}$ at $37^{\circ} \mathrm{C}$ with Krebs-Ringer-Phosphate (KRP) buffer. The buffer was then replaced with $1 \mathrm{ml}$ of fresh $\mathrm{KRP}$ containing $\left({ }^{3} \mathrm{H}\right)-2 \mathrm{DG}(0.4 \mu \mathrm{Ci} / \mathrm{ml}, 1.0 \mathrm{mmol} / 1$ final concentration). After 5 and $10 \mathrm{~min}$ at $37^{\circ} \mathrm{C}$ the uptake was stopped by washing the cells three times with ice-cold KRP containing $0.5 \%$ bovine serum albumin and $100 \mathrm{mmol} / \mathrm{l}$ D-glucose $\mathrm{pH} 7.4$. Cells were then solubilized with $1 \mathrm{ml} 0.1 \%$ sodium dodecyl sulphate, and the cell-incorporated radioactivity counted. Counts were normalized to the protein content in each well. Data are given as mean \pm SEM of five separate experiments

duced insulin secretion). The insulin released in the buffer was measured by radioimmunoassay, using rat insulin as a standard, and the data were expressed as $\mu U$ of insulin released $\cdot \mathrm{h}^{-1} \cdot \mathrm{mg}^{-1}$ of cell protein.

\section{Statistical analysis}

Statistical significance was assessed by Student's $t$-test for unpaired comparison.

\section{Results and discussion}

Under our experimental conditions, HIT cell $\left({ }^{3} \mathrm{H}\right)$-2DG uptake was linear up to $20 \mathrm{~min}$ (data not shown). In HIT cells cultured in the presence of $5.5 \mathrm{mmol} / \mathrm{l}$ glucose (G5.5) $\left({ }^{3} \mathrm{H}\right)-2 \mathrm{DG}$ uptake was $19.1 \pm 1.2 \mathrm{nmol} / 0.1 \mathrm{mg}$ after $5 \mathrm{~min}$, and $39.0 \pm 2.9 \mathrm{nmol} / 0.1 \mathrm{mg}$ after $10 \mathrm{~min}$ (mean $\pm \mathrm{SEM}$, $n=5$ ) (Fig. 1). When HIT cells were cultured in the presence of $16.7 \mathrm{mmol} / \mathrm{l}$ of glucose (G16.7), $\left({ }^{3} \mathrm{H}\right)-2 \mathrm{DG}$ uptake was significantly reduced, being $12.0 \pm 1.6$ and $22.2 \pm 2.6$ after 5 and $10 \mathrm{~min}$, respectively (mean $\pm \mathrm{SEM}$, $n=5, p<0.01$ ) (Fig. 1 ).

We then investigated the expression of the glucose transporter gene, under the same conditions. Two members of the glucose-transporter family were identified in HIT cells: the HEP-G ${ }_{2}$ erythrocyte glucose transporter (Glut-1) which is present in most cell types and in all mammalian cell lines in permanent culture [1], and the liver glucose transporter isoform (Glut-2) which is the most represented glucose-transporter in normal pancreatic Beta cells $[1,2]$. When HIT cells were cultured with high 
$28 \mathrm{~S}$

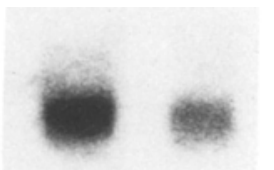

$18 \mathrm{~S}$ $\left(\frac{10}{10}\right.$

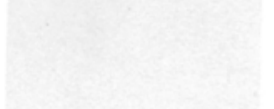
जु $\stackrel{\text { जु }}{\text { जु }}$

G5.5

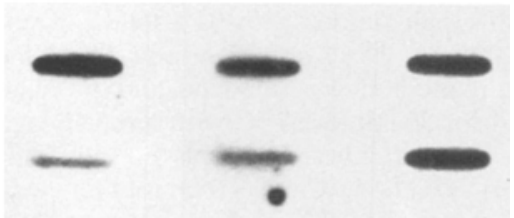

b

Glut.1

B-actin
Fig. 2a, b. HIT cells were cultured in RPMI-1640 medium supplemented with $10 \%$ fetal calf serum and containing glucose at either 5.5 or $16.7 \mathrm{mmol} / \mathrm{l}$. At the end of this period total cellular RNA was extracted in accordance with the guanidinium-isothiocyanate method. Panel a. Northern blot analysis of total RNA. RNA $(20 \mu \mathrm{g})$ was subjected to electrophoresis, and transferred to nitrocellulose paper. The nitrocellulose filters were hybridized with the denaturated cDNA probe of Glut-1 labelled with ${ }^{32} \mathrm{P}-\mathrm{dCTP}$ by nick translation. Glut-1 mRNA was clearly reduced after exposure of the cells to $16.7 \mathrm{mmol} / \mathrm{l}$ glucose. Panel b. Slot blot of total RNA. RNA $(5 \mu \mathrm{g})$ was immobilized to nitrocellulose filters and hybridized with the denaturated cDNA probe of Glut-1, Glut- 2 and $\beta$-actin labelled with ${ }^{32} \mathrm{P}$-dCTP by nick translation. Both Glut-1 and Glut-2 mRNA are clearly reduced in HIT cells exposed to $16.7 \mathrm{mmol} / \mathrm{l}$ glucose. No change in $\beta$-actin mRNA is evident. A representative of three separate experiments is shown

glucose (G16.7), Northern Blot analysis indicated a clear reduction of Glut-1 mRNA level compared to cells cultured at G.5.5 (Fig. 2a). To further analyse and quantitate this reduction we then performed slot-blot experiments using total RNA extracted from cells cultured in the presence of either G5.5 or G16.7. Cell RNA was hybridized with the cDNA probes of Glut-1, Glut-2 and $\beta$-actin. In three separate experiments the densitometric analysis indicated a significant reduction of both Glut-1 $(-63.9 \pm 4.1 \%$, mean \pm SEM $)$ and Glut-2 $(-48.9 \pm$ $3.2 \%$ ) mRNA in HIT cells cultured at G16.7 compared to cells cultured at G5.5. In the same experiments no change of $\beta$-actin mRNA was observed (Fig.2b), suggesting that the effect of high glucose was specific for the glucosetransporter mRNAs.

Under the same experimental conditions, the glucoseinduced insulin release was reduced in HIT cells cultured at G16.7 compared to cells cultured at G5.5 $\left(715 \pm 19 \mu \mathrm{U} \cdot \mathrm{h}^{-1} \cdot \mathrm{mg}^{-1}\right.$ vs $1301 \pm 28 \mu \mathrm{U} \cdot \mathrm{h}^{-1} \cdot \mathrm{mg}^{-1}$, respectively, mean $\pm \mathrm{SEM}, n=3, p<0.05$ ).

Our studies indicate that exposure of HIT pancreatic cells to $16.7 \mathrm{mmol} / \mathrm{l}$ glucose for $48 \mathrm{~h}$ can decrease glucose transport, Glut-1 and Glut-2 glucose transporter mRNA levels, and at the same time, impair glucose-induced insulin release. In our model with HIT pancreatic cells both Glut-1 and Glut-2 gene expression was regulated by glucose. Our data suggest that exposure to high glucose concentrations, by decreasing glucose carrier mRNA levels, can cause a decreased synthesis of the two transporters and eventually lead to decreased glucose transport. This is in keeping with previous observations in other cell types showing that exposure to high glucose reduces the number of glucose transporters and that this effect is associated with decreased glucose transport activity [4]. Therefore, the mechanism observed in HIT pancreatic cells may mirror a general mechanism through which glucose downregulates its own transport. To our knowledge, these are the first data available on the glucose transporter expression in HIT cells, the most used Beta-cell line maintaining glucose-induced insulin release. Previous data have demonstrated the presence of both Glut-1 and Glut-2 glucose transporters in another pancreatic Beta-cell line (rat insulinoma RIN cells) [2]. The inability of RIN cells to respond to glucose has been attributed to the aberrent expression of Glut-1 [2]. Our data on HIT cells, however, do not support this hypothesis, since also HIT cells that maintain a clear ability to increase insulin secretion in response to glucose have significant amounts of Glut-1. The relative expression of the two glucose transporters in the two cell lines may explain this discrepancy. However, the effect of the Glut-1 expression on the glucose-induced insulin secretion remains to be clarified.

We have also demonstrated that in HIT cells, exposure to high glucose impairs glucose-induced insulin release. A similar effect of glucose has already been reported in pancreatic islets and in purified Beta cells [5]. At variance with these models, however, in HIT cells glucose transport is the rate-limiting step for insulin secretion [6]. Our data suggest a close relationship between these two functions. Impaired glucose transport, by altering the glucose-sensing mechanism may, in turn, decrease insulin release. Recently, a similar relationship between glucose transporter mRNA levels and glucose-induced insulin release has been observed in pancreatic islets in vivo. In chronically hypoglycaemic rats Chen et al. [7] demonstrated a reduction of Glut- 2 mRNA levels under experimental conditions in which glucose-induced insulin release was also reduced. In the same model, a hyperglycaemic clamp was associated with both increased Beta-cell Glut-2 mRNA levels and increased proinsulin synthesis. If this relationship is also effective in humans, the presence of IgGs that inhibit glucose uptake described in recent onset Type 1 (insulin-dependent) diabetic patients, may contribute to the impairment of glucose-induced insulin release in these patients [8].

In conclusion, our data demonstrate that the chronic exposure of HIT pancreatic cells to high glucose may down-regulate glucose transporter mRNA levels, glucose transport, and glucose-induced insulin secretion in a coordinate manner. This model, therefore, may prove useful for studying the mechanism whereby alterations of the glucose transport system may affect insulin secretion in pancreatic Beta cells. 
Note: After this paper was submitted we became aware of two recent publications $[9,10]$ showing in animal models of non-insulin-dependent diabetes a decreased expression of the Beta-cell glucose transporter in pancreatic islets unresponsive to glucose, further supporting the view that this transporter may play a role in the glucosesensing mechanism.

\section{References}

1. Mueckler M (1990) Family of glucose transporter genes. Implications for glucose homeostasis and diabetes. Diabetes 39: 6-11

2. Thorens B, Sarkar HK, Kaback HR, Lodish HF (1988) Cloning and functional expression in bacteria of a novel glucose transporter present in liver, intestine, kidney, and Beta-pancreatic islet cells. Cell 55: 281-290

3. Van Putten JPM, Krans HMJ (1985) Glucose as a regulator of insulin-sensitive hexose uptake in 3T3 adipocytes. J Biol Chem 260: 7996-8001

4. Sasson S, Cerasi E (1986) Substrate regulation of the glucose transport system in rat skeletal muscle. J Biol Chem 261: 1682716833

5. Purrello F, Vetri M, Gatta C, Gullo D, Vigneri R (1989) Effects of high glucose on insulin secretion by isolated islets and purified beta cells and possible role of glycosylation. Diabetes 38: 14171422

6. Ashcroft SJH, Stubbs M (1987) The glucose sensor in HIT cells is the glucose transporter. FEBS Lett 219:311-315
7. Chen L, Alam T, Johnson JH, Hughes S, Newgard B, Unger RH (1990) Regulation of Beta-cell glucose transporter gene expression. Proc Natl Acad Sci USA 87: 4088-4092

8. Johnson JH, Crider BP, McCorkle K, Alford M, Unger RH (1990) Inhibition of glucose transport into rat islet cells by immunoglobulins from patients with new-onset insulin-dependent diabetes mellitus. N Engl J Med 322: 653-659

9. Thorens B, Weir G, Leahy JL, Lodish HF, Bonner-Weir S (1990) Reduced expression of the liver/beta-cell glucose transporter isoform in glucose-insensitive pancreatic beta cells of diabetic rats. Proc Natl Acad Sci USA 87: 6492-6496

10. Johnson JH, Ogawa A, Chen L, Orci L, Newgard CB, Alam T, Unger RH (1990) Underexpression of $\beta$ cell high $\mathrm{K}_{\mathrm{m}}$ glucose transporters in noninsulin-dependent diabetes. Science 250:546549

Received: 5 November 1990

and in revised form: 17 December 1990

Dr. F. Purrello

Cattedra di Endocrinologia

Università di Catania

Ospedale Garibaldi

Piazza S. Maria di Gesù

I-95123 Catania

Italy 